\title{
IMPLEMENTATION OF THE OSTRC HANDBALL INJURY PREVENTION EXERCISES IN PROFESSIONAL HANDBALL
}

\author{
Wesam Saleh A. Al Attar ${ }^{1,2,3 \mathrm{ABCDE}}$, Nawaf Al Masoudi ${ }^{1 B C D E}$, Ali Al Zubeadi ${ }^{1 \mathrm{CDE}}$, Ahmed Qasem ${ }^{1 \mathrm{BCDE}}$ \\ ${ }^{1}$ Umm Al Qura University \\ ${ }^{2}$ The University of Sydney \\ ${ }^{3}$ University of Basel
}

Authors' Contribution: A - Study design; B - Data collection; C - Statistical analysis; D - Manuscript Preparation; E - Funds Collection

Corresponding Author: Wesam Saleh A. Al Attar, E-mail: wsattar@uqu.edu.sa

Accepted for Publication: May 18, 2021

Published: June 25, 2021

DOI: 10.17309/tmfv.2021.2.06

\begin{abstract}
Purpose. The Oslo Sports Trauma Research Center (OSTRC) handball injury prevention exercise is an evidence-based injury prevention exercise designed to prevent handball injury. This study aimed to assess the implementation of the OSTRC handball injury prevention exercises among professional handball players in the Gulf Cooperation Council (GCC) countries.

Materials and methods. A web-based survey to acquire information regarding the implementation of OSTRC handball injury prevention exercises was distributed to 267 professional handball players in six GCC countries.

Results. A total of 250 handball players from the GCC countries responded to the survey (response rate 93.6\%). The mean $( \pm$ SD (Standard Deviation)) of the total implementation score was $13( \pm 2.558)$, with no statistically significant difference between the GCC countries, with a P-value of 0.123. The highest mean score was shown from Bahrain at $13.60( \pm 2.614)$, while the lowest was from Qatar at $12.10( \pm 2.427)$.

Conclusions. A low implementation level of the OSTRC handball prevention exercises among the handball players in the GCC countries was reported in the current study.

Keywords: athletic injuries, surveys and questionnaires, exercises, sports.
\end{abstract}

\section{Introduction}

Handball is a sports game founded in 1946 and for the first time in the Olympic games in 1972 (Luig et al., 2018). The fam of this sport game has increased in recent years, and currently, worldwide there are 25 million players (Moller, Attermann, Myklebust, \& Wedderkopp, 2012), including male, female, senior, and youth players (Alesi et al., 2019). There are multiple beneficial effects derived from handball practice, such as improvements in cardiovascular, metabolic, muscular, and psychosocial health (Engebretsen et al., 2013; Hornstrup et al., 2019; Póvoas et al., 2012), this sport game presents a high injury risk (Kniubaite, Skarbalius, Clemente, \& Conte, 2019). Mainly because of high-intensity specific demands, like change in direction, jumps with abrupt landings and repetitive throws, frequent physical contact with other players (Fredriksen, Cools, Bahr, \& Myklebust, 2020; Tsigilis \& Hatzimanouil, 2005). Low physical fitness, wrong technique, lack of flexibility, and inadequate rehabilitation

(c) Wesam Saleh A. Al Attar, Nawaf Al Masoudi, Ali AL Zubeadi, Ahmed Qasem, 2021. treatment of injuries have been reported as risk factors related to the occurrence of injuries (Ekstrand, 2013; Hägglund et al., 2013). Also, the high intensities and training volumes increase the injury incidence (Hägglund et al., 2013). In this regard, injuries are associated with negative results like team success reduction (Bahr \& Holme, 2003), costs increased related to treatments (Øiestad, Holm, \& Risberg, 2018), and the risk of suffering from new injuries (O’Brien, Finch, Pruna, \& McCall, 2019). Besides, injuries have long-term health consequences influencing the quality of life and career (Van Mechelen, Hlobil, \& Kemper, 1992). Therefore, a key positive impact for both players' and teams' performance in reducing the injury incidence. To comprehensively address this issue, important to apply injury prevention approach (Roald Bahr, Clarsen, \& Ekstrand, 2018). Van Mechelen et al. (Van Mechelen et al., 1992) confirmed that developing effective injury prevention strategies analysis as the first step, analysis several studies of handball players' injury profile, showing the incidence of 4.1 to 12.4 injuries per 1000 hours overall exposure (Giroto, Hespanhol Junior, Gomes, \& Lopes, 2017; Olsen, Myklebust, Engebretsen, \& Bahr, 2006; Rafnsson, 
Valdimarsson, Sveinsson, \& Árnason, 2019) confirming that match injury incidence is significantly higher than training injury incidence. Additionally, the lower extremities injuries more than upper extremities injuries, affecting the ankle, knee, and head, with ligament sprains and muscle strains being the most type of injuries (Giroto et al., 2017; Hopkins, Marshall, Quarrie, \& Hume, 2007; Olsen et al., 2006). Despite the good number of epidemiological studies focused on handball players, there is a discrepancy of definitions addressing injuries and data collection procedures, which suggests a requirement to perform a more detailed study of the injury profile in handball to expand and clarify the present knowledge regarding handball injuries.

Injuries are considered a complex (Mayer, Rühlemann, \& Jäger, 2019) produced by the interaction of multiple risk factors (O'Brien et al., 2019), where players' characteristics (e.g., gender or age) are the foremost influential ones (Nielsen \& Yde, 1988), can be explained by different game behaviours and physical contact among players (Rafnsson et al., 2019). Additionally, training load performed by the players during matches and training sessions should be taken into consideration when injury risk factors are analysed (O'Brien et al., 2019) surveyed to analyse the implementation of evidencebased injury prevention exercises to commonest injuries among soccer coaches and players. A significant amount of research was conducted to better understand sports specific injuries, body parts most at risk, how these injuries occur, what causes them and how to prevent them. Therefore, this paper aims to assess the implementation of Oslo Sports Trauma Research Center (OSTRC) handball injury prevention exercises among in professional handball players in the Gulf Cooperation Council (GCC) countries.

\section{Materials and methods}

\section{Survey Development}

To the authors' knowledge, no validated surveys are addressing the implementation of injury prevention exercise among worldwide handball players. Therefore, a survey was developed specifically for the current study. Respondents were prompted to answer every question provided in the survey before the next set of questions was presented. A respondent should answer a maximum of 33 questions categorized into three sections: (1) the study invitation and participation agreement, (2) socio-demographics questions, and (3) the implementation of OSTRC handball injury prevention exercises.

Items were in the form of multiple-choice questions and scoring of each item was dichotomous (correct answer $=1$; incorrect answer $=0$ ). The maximum score of the survey is the sum of all items (a score of 27) and transformed into a percentage score for ease of data analysis and data reporting. When questions are answered correctly, higher scores reflect more implementation and knowledge (possible range of correct answers $0-27$ ). The respondents were able to see the total score, correct answers, and the questions they missed immediately after submission. The survey was available in English and Arabic language supported by videos demonstrating each exercise. This project was reviewed and ethically approved by the Biomedical Ethics Committee at Umm Al Qura University. Approval Number. HAPO02K012202010465. A consent was obtained from each participant included in the study before data collection begins. After obtaining permission from each participant and assuring their confidentiality, the participants were then asked to fill out the questionnaire. All participants were informed that their participation was entirely voluntary and confidential.

\section{Survey Dissemination}

A survey invitation was distributed through the Saudi Arabia, UAE, Kuwait, Bahrain, Oman, and Qatar Handball Federation. The invitation provided a brief background about the survey and encouraged to participate. Once the participants read the scope and aim of the survey, they were asked to provide informed consent and access the survey. The survey was filled anonymously and electronically via a web-based form. Responses were collected from June to October 2020.

\section{Sample Size and Statistical analysis}

Considering a $6 \%$ margin of error at a $95 \%$ confidence level, 267 professional handball players in six GCC countries were invited to participate.

Responses were organized in Microsoft Excel 2010 (Microsoft Corporation, Redmond, Washington, USA) and analysed using Statistical Package for the Social Sciences (SPSS) version 24.0 (IBM Corp., Armonk, New York, USA). Descriptive statistics were computed to describe the sample characteristics and survey data. One-way Welch ANOVA was used to determine differences in the overall survey score.

\section{Results}

A total of 250 handball players from the GCC countries responded to the survey (response rate 93.6\%). The highest percentage of the participants (20.4\%) was from Saudi Arabia, while participation from the remaining GCC countries was almost similar (around 16\% from each), as shown in table (1).

The rate of implementation of each of the OSTRC injury prevention exercises is shown in table (2). Overall, the implementation rate ranged from $44.8 \%$ for the $\mathrm{Y}$ fall exercise to $55.6 \%$ for the jump and push, and shoulder rotation exercises at $55.6 \%$ for each, as shown in table (2).

The comparison among the GCC countries with respect to the mean of the total implementation score is shown in table (3). The mean $( \pm S D)$ of the total implementation score was 13 ( \pm 2.558$)$. Generally, there was no statistically significant difference between the GCC countries in the mean of the total implementation score, with a P-value of 0.123 . The highest mean score was shown from Bahrain at $13.60( \pm 2.614)$ followed by the United Arab Emirates (UAE) at $13.34( \pm 2.640)$.

Table 1. Frequencies and percentages of all participant from different countries of the Gulf Cooperation Council

\begin{tabular}{lcc}
\hline \multicolumn{1}{c}{ Indicators } & Frequency & Percent \\
\hline Saudi Arabia & 51 & $20.4 \%$ \\
Bahrain & 42 & $16.8 \%$ \\
Kuwait & 42 & $16.8 \%$ \\
Oman & 34 & $13.6 \%$ \\
Qatar & 41 & $16.4 \%$ \\
United Arab Emirates & 40 & $16.0 \%$ \\
Total & 250 & $100.0 \%$ \\
\hline
\end{tabular}


Table 2. Percentages and frequencies for different points

\begin{tabular}{lc}
\hline \multicolumn{1}{c}{ Exercises } & Frequency (\%) \\
\hline Triangle run & $129(51.6 \%)$ \\
Run with backwards throws & $122(48.8 \%)$ \\
Run with foot plant & $119(47.6 \%)$ \\
Jump \& push & $139(55.6 \%)$ \\
Side lying rotation & $114(45.6 \%)$ \\
Bow and arrow & $134(53.6 \%)$ \\
Shoulder external rotation & $139(55.6 \%)$ \\
Push up passes & $119(47.6 \%)$ \\
Single-leg deadlift with partner & $138(55.2 \%)$ \\
Backwards throws & $128(51.2 \%)$ \\
Forwards speed-skating jumps & $131(52.4 \%)$ \\
Run and jump: Double-leg landing & $133(53.2 \%)$ \\
Rotating jump with push: Double-leg landing & $124(49.6 \%)$ \\
Hip flexors stretch + & $116(46.4 \%)$ \\
Shoulder press & $126(50.4 \%)$ \\
Shoulder external rotation+ & $115(46.0 \%)$ \\
Push up passes+ & $116(46.4 \%)$ \\
Drop \& catch & $121(48.4 \%)$ \\
Bounding & $119(47.6 \%)$ \\
Run and jump: Single-leg landing & $132(52.8 \%)$ \\
Rotating jump with push: Single-leg landing & $114(45.6 \%)$ \\
Kneeling lunge with rotation & $138(55.2 \%)$ \\
Y fall & $112(44.8 \%)$ \\
Overhead shoulder strength & $130(52.0 \%)$ \\
Push up + backwards toe walk & $126(50.4 \%)$ \\
Backwards throwing + & $117(46.8 \%)$ \\
\hline
\end{tabular}

Table 3. Comparison among the Countries of the Gulf Cooperation Council with respect to total score.

\begin{tabular}{llllcccc}
\hline \multicolumn{1}{c}{ Indicators } & N & Mean & SD & Median & Min & Max & ${ }^{*}$ P-value \\
\hline Saudi Arabia & 51 & 12.86 & 2.615 & 13 & 8 & 20 & \\
Bahrain & 42 & 13.60 & 2.614 & 14 & 7 & 18 & \\
Kuwait & 42 & 13.02 & 2.523 & 13 & 8 & 19 & \\
Oman & 34 & 13.06 & 2.348 & 14 & 8 & 18 & 0.123 \\
Qatar & 41 & 12.10 & 2.427 & 12 & 7 & 17 & \\
United Arab & 40 & 13.43 & 2.640 & 13 & 8 & 18 & \\
Emirates & & & & & & & \\
Total & 250 & 13.00 & 2.558 & 13 & 7 & 20 & \\
\hline
\end{tabular}

Table note: * One-way analysis of variance (ANOVA).

On the other hand, the lowest implementation rate was found in Qatar at $12.10( \pm 2.427)$

The comparison between the GCCs by the implementation of each exercise is shown in table (4). Overall, there were no significant differences between the GCCs in the implementation rates of all the addressed exercises since all $\mathrm{P}$ values were $>0.05$. A borderline significant difference (0.056) was shown with the run and jump: single-leg landing exercise, being highly implemented in Saudi Arabia at 60.8\%, and the lowest in UAE at $37.5 \%$.

\section{Discussion}

This study aimed to assess the level of implementation of the OSTRC handball injury prevention exercises among handball players in the GCCs, and to the best of our knowledge, this is the first study to address this topic. The results revealed low implementation rates of the assessed exercises that ranged from $44.8 \%$ to $55.6 \%$.

The scarcity of similar data in the literature makes comparing the current study findings difficult. However, in line with the current study findings of low implementation rates of handball injury prevention exercises, previous randomized controlled trials (RCTs) showed that despite the high effectiveness of the evidence-based injury prevention training in reducing musculoskeletal injuries by approximately $40 \%$, such training has limited public health impact (Emery, Roy, Whittaker, Nettel-Aguirre, \& Van Mechelen, 2015; Rössler et al., 2014; Soomro et al., 2016). This is mainly because the training is not widely or properly implemented or sustained (Donaldson \& Finch, 2013; Finch \& Donaldson, 2010).

Unfortunately, the reasons for non-implementation in the current study were not addressed. A recently published study by Ageberg E et al. (Ageberg et al., 2019), suggested that activities to facilitate the implementation of an injury prevention intervention for team handball players should focus on ensuring that both the players and coaches know and understand the principles, importance, and benefits of such training. In addition, Joy EA et al. (Joy et al., 2013) reported that inadequate implementation knowledge is one of the major obstacles for adopting a prevention program for anterior cruciate ligament injury. Therefore, based on the current study results it is highly recommended that the OSTRC handball injury prevention program should reach and involve all stakeholders, including players, coaches, and clubs and governing bodies. Moreover, for promoting the implementation, it is essential to assure understanding of the relevant benefits of the injury prevention exercise program for all stakeholders, enhancing program fidelity, and encouraging maintenance by establishing policies and procedures at the team, club, and governing body levels.

As with any study, the current study has its limitations. Besides handball players, who were invited to participate in this study, coaches and physical therapists are other relevant participants potentially affecting the success of the implementation, however, they were not included in the current study. In addition, implementation of a prevention program is a complex process and the word 'implement,' which was assessed in the current study, is only facet. Therefore, future research should aim to more precisely define and allocate the varied factors contributing to concepts such as program usage, feasibility, or suitability. Despite these limitations, this is the first study in this area, and data was collected from handball players from the whole GCCs, therefore, the result could be generalized to the region.

\section{Conclusions}

Overall, the implementation levels of the OSTRC handball prevention exercises among the handball players in the GCC countries is considered low. Future studies addressing the barriers for non-implementation and how to overcome them are needed.

\section{Acknowledgement}

The author(s) would like to thank all GCC Handball Federations for distributing the survey and all players who participated in this project.

\section{Conflict of interest}

The author(s) declared no potential conflicts of interest with respect to the research, authorship, and/or publication of this article. 
Wesam Saleh A. Al Attar, Nawaf Al Masoudi, Ali AL Zubeadi, \& Ahmed Qasem, (2021). Implementation of the OSTRC Handball Injury Prevention Exercises in Professional Handball

Table 4. Comparison among the Countries of the Gulf Cooperation Councilwith respect to different points.

\begin{tabular}{|c|c|c|c|c|c|c|c|}
\hline \multirow{3}{*}{ Indicators } & \multicolumn{6}{|c|}{ Countries } & \multirow{3}{*}{ P-value } \\
\hline & \multirow{2}{*}{$\begin{array}{c}\text { Saudi } \\
\text { Arabia }\end{array}$} & \multirow{2}{*}{$\begin{array}{c}\text { Bahrain } \\
(n=42)\end{array}$} & \multirow{2}{*}{$\begin{array}{c}\text { Kuwait } \\
(n=42)\end{array}$} & \multirow{2}{*}{$\begin{array}{c}\text { Oman } \\
(n=34)\end{array}$} & \multirow{2}{*}{$\frac{\text { Qatar }}{(n=41)}$} & \multirow{2}{*}{$\begin{array}{c}\text { U.A. E } \\
(n=40)\end{array}$} & \\
\hline & & & & & & & \\
\hline \multirow{2}{*}{ Triangle run } & 25 & 24 & 25 & 14 & 21 & 20 & \multirow{2}{*}{0.664} \\
\hline & $49.0 \%$ & $57.1 \%$ & $59.5 \%$ & $41.2 \%$ & $51.2 \%$ & $50.0 \%$ & \\
\hline \multirow{2}{*}{ Run with backwards throws } & 25 & 19 & 19 & 16 & 23 & 20 & \multirow[b]{2}{*}{0.928} \\
\hline & $49.0 \%$ & $45.2 \%$ & $45.2 \%$ & $47.1 \%$ & $56.1 \%$ & $50.0 \%$ & \\
\hline \multirow{2}{*}{ Run with foot plant } & 25 & 26 & 22 & 13 & 13 & 20 & \multirow{2}{*}{0.097} \\
\hline & $49.0 \%$ & $61.9 \%$ & $52.4 \%$ & $38.2 \%$ & $31.7 \%$ & $50.0 \%$ & \\
\hline \multirow[b]{2}{*}{ Jump \& push } & 29 & 23 & 20 & 22 & 17 & 28 & \multirow[b]{2}{*}{0.111} \\
\hline & $56.9 \%$ & $54.8 \%$ & $47.6 \%$ & $64.7 \%$ & $41.5 \%$ & $70.0 \%$ & \\
\hline \multirow{2}{*}{ Side lying rotation } & 26 & 20 & 15 & 14 & 17 & 22 & \\
\hline & $51.0 \%$ & $47.6 \%$ & $35.7 \%$ & $41.2 \%$ & $41.5 \%$ & $55.0 \%$ & 0.508 \\
\hline & 26 & 21 & 20 & 22 & 24 & 21 & \\
\hline Bow and arrow & $51.0 \%$ & $50.0 \%$ & $47.6 \%$ & $64.7 \%$ & $58.5 \%$ & $52.5 \%$ & 0.689 \\
\hline & 26 & 24 & 27 & 15 & 23 & 24 & \\
\hline Shoulder external rotation & $51.0 \%$ & $57.1 \%$ & $64.3 \%$ & $44.1 \%$ & $56.1 \%$ & $60.0 \%$ & 0.564 \\
\hline & 28 & 20 & 18 & 18 & 18 & 17 & \\
\hline Push up passes & $54.9 \%$ & $47.6 \%$ & $42.9 \%$ & $52.9 \%$ & $43.9 \%$ & $42.5 \%$ & 0.777 \\
\hline Single ler dendlift with portner & 26 & 25 & 26 & 18 & 19 & 24 & 0670 \\
\hline Single-leg deadlift with partner & $51.0 \%$ & $59.5 \%$ & $61.9 \%$ & $52.9 \%$ & $46.3 \%$ & $60.0 \%$ & $0.6 / 0$ \\
\hline & 31 & 28 & 20 & 15 & 17 & 17 & \\
\hline Backwards throws & $60.8 \%$ & $66.7 \%$ & $47.6 \%$ & $44.1 \%$ & $41.5 \%$ & $42.5 \%$ & 0.089 \\
\hline & 25 & 19 & 24 & 17 & 22 & 24 & \\
\hline Forwards speed-skating jumps & $49.0 \%$ & $45.2 \%$ & $57.1 \%$ & $50.0 \%$ & $53.7 \%$ & $60.0 \%$ & 0.775 \\
\hline & 23 & 29 & 17 & 20 & 20 & 24 & \\
\hline Run and jump: Double-leg landing & $45.1 \%$ & $69.0 \%$ & $40.5 \%$ & $58.8 \%$ & $48.8 \%$ & $60.0 \%$ & 0.081 \\
\hline Rotating jump with push: Double-leg & 24 & 22 & 17 & 21 & 22 & 18 & \\
\hline landing & $47.1 \%$ & $52.4 \%$ & $40.5 \%$ & $61.8 \%$ & $53.7 \%$ & $45.0 \%$ & 0.510 \\
\hline & 23 & 23 & 20 & 11 & 18 & 21 & \\
\hline Hip flexors stretch + & $45.1 \%$ & $54.8 \%$ & $47.6 \%$ & $32.4 \%$ & $43.9 \%$ & $52.5 \%$ & 0.461 \\
\hline & 25 & 22 & 24 & 13 & 20 & 22 & \\
\hline Shoulder press & $49.0 \%$ & $52.4 \%$ & $57.1 \%$ & $38.2 \%$ & $48.8 \%$ & $55.0 \%$ & 0.660 \\
\hline & 25 & 22 & 17 & 19 & 16 & 16 & \\
\hline Shoulder external rotation+ & $49.0 \%$ & $52.4 \%$ & $40.5 \%$ & $55.9 \%$ & $39.0 \%$ & $40.0 \%$ & 0.534 \\
\hline & 18 & 19 & 20 & 19 & 19 & 21 & \\
\hline Push up passes+ & $35.3 \%$ & $45.2 \%$ & $47.6 \%$ & $55.9 \%$ & $46.3 \%$ & $52.5 \%$ & 0.493 \\
\hline & 22 & 16 & 22 & 20 & 17 & 24 & \\
\hline Drop \& catch & $43.1 \%$ & $38.1 \%$ & $52.4 \%$ & $58.8 \%$ & $41.5 \%$ & $60.0 \%$ & 0.218 \\
\hline & 27 & 18 & 21 & 17 & 15 & 21 & \\
\hline Bounding & $52.9 \%$ & $42.9 \%$ & $50.0 \%$ & $50.0 \%$ & $36.6 \%$ & $52.5 \%$ & 0.621 \\
\hline & 31 & 24 & 24 & 22 & 16 & 15 & \\
\hline Run and jump: Single-leg landing & $60.8 \%$ & $57.1 \%$ & $57.1 \%$ & $64.7 \%$ & $39.0 \%$ & $37.5 \%$ & 0.056 \\
\hline & 26 & 20 & 22 & 12 & 15 & 19 & \\
\hline Rotating jump with push: Single-leg landing & $51.0 \%$ & $47.6 \%$ & $52.4 \%$ & $35.3 \%$ & $36.6 \%$ & $47.5 \%$ & 0.507 \\
\hline Kneeling lunge with rotation & 27 & 23 & 18 & 23 & 23 & 24 & 0.391 \\
\hline & $52.9 \%$ & $54.8 \%$ & $42.9 \%$ & $67.6 \%$ & $56.1 \%$ & $60.0 \%$ & 0.591 \\
\hline$Y f_{2} l l$ & 21 & 13 & 26 & 17 & 15 & 20 & \\
\hline Y tall & $41.2 \%$ & $31.0 \%$ & $61.9 \%$ & $50.0 \%$ & $36.6 \%$ & $50.0 \%$ & 0.064 \\
\hline & 25 & 25 & 23 & 16 & 22 & 19 & \\
\hline Overhead shoulder strength & $49.0 \%$ & $59.5 \%$ & $54.8 \%$ & $47.1 \%$ & $53.7 \%$ & $47.5 \%$ & 0.854 \\
\hline Push un + backwards toe walk & 22 & 23 & 22 & 18 & 21 & 20 & \\
\hline Push up + backwards toe walk & $43.1 \%$ & $54.8 \%$ & $52.4 \%$ & $52.9 \%$ & $51.2 \%$ & $50.0 \%$ & 0.906 \\
\hline & 25 & 23 & 18 & 12 & 23 & 16 & 0368 \\
\hline Backwards throwing + & $49.0 \%$ & $54.8 \%$ & $42.9 \%$ & $35.3 \%$ & $56.1 \%$ & $40.0 \%$ & 0.368 \\
\hline
\end{tabular}

\section{References}

Luig, P., Krutsch, W., Nerlich, M., Henke, T., Klein, C., Bloch, H., Platen, P., \& Achenbach, L. (2018). Increased injury rates after the restructure of Germany's national second league of team handball. Knee Surgery, Sports Traumatology, Arthroscopy, 26(7), 1884-1891. https://doi.org/10.1007/s00167-018-4851-4
Moller, M., Attermann, J., Myklebust, G., \& Wedderkopp, N. (2012). Injury risk in Danish youth and senior elite handball using a new SMS text messages approach. British Journal of Sports Medicine, 46(7), 531. https://doi.org/10.1136/bjsports-2012-091022

Alesi, M., Gómez-López, M., Chicau Borrego, C., Monteiro, D., \& Granero-Gallegos, A. (2019). Effects of a Motivational 
Climate on Psychological Needs Satisfaction, Motivation and Commitment in Teen Handball Players. International journal of environmental research and public health, 16(15), 2702. https://doi.org/10.3390/ijerph16152702

Engebretsen, L., Soligard, T., Steffen, K., Alonso, J. M., Aubry, M., Budgett, R., Dvorak, J., Jegathesan, M., Meeuwisse, W. H., Mountjoy, M., Palmer-Green, D., Vanhegan, I., \& Renström, P. A. (2013). Sports injuries and illnesses during the London Summer Olympic Games 2012. British Journal of Sports Medicine, 47(7), 407. https://doi.org/10.1136/bjsports-2013-092380

Hornstrup, T., Løwenstein, F. T., Larsen, M. A., Helge, E. W., Póvoas, S., Helge, J. W., Nielsen, J. J., Fristrup, B., Andersen, J. L., Gliemann, L., Nybo, L., \& Krustrup, P. (2019). Cardiovascular, muscular, and skeletal adaptations to recreational team handball training: A randomized controlled trial with young adult untrained men. European Journal of Applied Physiology, 119(2), 561-573. https://doi.org/10.1007/s00421-018-4034-5

Póvoas, S. C. A., Seabra, A. F. T., Ascensão, A. A. M. R., Magalhães, J., Soares, J. M. C., \& Rebelo, A. N. C. (2012). Physical and Physiological Demands of Elite Team Handball. The Journal of Strength \& Conditioning Research, 26(12). https://doi.org/10.1519/JSC.0b013e318248aeee

Kniubaite, A., Skarbalius, A., Clemente, F. M., \& Conte, D. (2019). Quantification of external and internal match loads in elite female team handball. Biology of sport, 36(4), 311-316. https://doi.org/10.5114/biolsport.2019.88753

Fredriksen, H., Cools, A., Bahr, R., \& Myklebust, G. (2020). Does an effective shoulder injury prevention program affect risk factors in handball? A randomized controlled study. Scandinavian Journal of Medicine \& Science in Sports, 30(8), 1423-1433.

https://doi.org/10.1111/sms.13674

Tsigilis, N., \& Hatzimanouil, D. (2005). Injuries in handball: Examination of the risk factors. European Journal of Sport Science, 5(3), 137-142. https://doi.org/10.1080/17461390500221610

Ekstrand, J. (2013). Keeping your top players on the pitch: The key to football medicine at a professional level. British Journal of Sports Medicine, 47(12), 723. https://doi.org/10.1136/bjsports-2013-092771

Hägglund, M., Waldén, M., Magnusson, H., Kristenson, K., Bengtsson, H., \& Ekstrand, J. (2013). Injuries affect team performance negatively in professional football: An 11year follow-up of the UEFA Champions League injury study. British Journal of Sports Medicine, 47(12), 738. https://doi.org/10.1136/bjsports-2013-092215

Bahr, R., \& Holme, I. (2003). Risk factors for sports injuries a methodological approach. British journal of sports medicine, 37(5), 384-392. https://doi.org/10.1136/bjsm.37.5.384

Øiestad, B. E., Holm, I., \& Risberg, M. A. (2018). Return to pivoting sport after ACL reconstruction: Association with osteoarthritis and knee function at the 15-year follow-up. British Journal of Sports Medicine, 52(18), 1199. https://doi.org/10.1136/bjsports-2017-097718

O’Brien, J., Finch, C. F., Pruna, R., \& McCall, A. (2019). A new model for injury prevention in team sports: The Teamsport Injury Prevention (TIP) cycle. Science and Medicine in Football, 3(1), 77-80.

https://doi.org/10.1080/24733938.2018.1512752

van Mechelen, W., Hlobil, H., \& Kemper, H. C. G. (1992). Incidence, Severity, Aetiology and Prevention of Sports Injuries. Sports Medicine, 14(2), 82-99. https://doi.org/10.2165/00007256-199214020-00002

Bahr, R., Clarsen, B., \& Ekstrand, J. (2018). Why we should focus on the burden of injuries and illnesses, not just their incidence. British Journal of Sports Medicine, 52(16), 1018. https://doi.org/10.1136/bjsports-2017-098160

Giroto, N., Hespanhol Junior, L. C., Gomes, M. R. C., \& Lopes, A. D. (2017). Incidence and risk factors of injuries in Brazilian elite handball players: A prospective cohort study. Scandinavian Journal of Medicine \& Science in Sports, 27(2), 195-202. https://doi.org/10.1111/sms.12636

Olsen, O.-E., Myklebust, G., Engebretsen, L., \& Bahr, R. (2006). Injury pattern in youth team handball: A comparison of two prospective registration methods. Scandinavian Journal of Medicine \& Science in Sports, 16(6), 426-432. https://doi.org/10.1111/j.1600-0838.2005.00484.x

Hopkins, W.G., Marshall, S.W., Quarrie, K.L., \& Hume, P.A. (2007). Risk factors and risk statistics for sports injuries. Clin J Sport Med, 17(3), 208-10. https://doi.org/10.1097/JSM.0b013e3180592a68

Mayer, C., Rühlemann, A., \& Jäger, M. (2019). Verletzungen und deren Prävention beim Handball. Der Orthopäde, 48(12), 1036-1041. https://doi.org/10.1007/s00132-019-03822-6

Nielsen, A. B., \& Yde, J. (1989). Epidemiology and traumatology of injuries in soccer. The American Journal of Sports Medicine, 17(6), 803-807. https://doi.org/10.1177/036354658901700614

Rafnsson, E. T., Valdimarsson, Ö., Sveinsson, T., \& Árnason, Á. (2019). Injury Pattern in Icelandic Elite Male Handball Players. Clinical Journal of Sport Medicine, 29(3), 232-237. https://doi.org/10.1097/JSM.0000000000000499

Emery, C. A., Roy, T.-O., Whittaker, J. L., Nettel-Aguirre, A., \& van Mechelen, W. (2015). Neuromuscular training injury prevention strategies in youth sport: A systematic review and meta-analysis. British Journal of Sports Medicine, 49(13), 865. https://doi.org/10.1136/bjsports-2015-094639

Rössler, R., Donath, L., Verhagen, E., Junge, A., Schweizer, T., \& Faude, O. (2014). Exercise-Based Injury Prevention in Child and Adolescent Sport: A Systematic Review and Meta-Analysis. Sports Medicine, 44(12), 1733-1748. https://doi.org/10.1007/s40279-014-0234-2

Soomro, N., Sanders, R., Hackett, D., Hubka, T., Ebrahimi, S., Freeston, J., \& Cobley, S. (2015). The Efficacy of Injury Prevention Programs in Adolescent Team Sports: A Metaanalysis. The American Journal of Sports Medicine, 44(9), 2415-2424. https://doi.org/10.1177/0363546515618372

Donaldson, A., \& Finch, C. F. (2013). Applying implementation science to sports injury prevention. British Journal of Sports Medicine, 47(8), 473. https://doi.org/10.1136/bjsports-2013-092323

Finch, C. F., \& Donaldson, A. (2010). A sports setting matrix for understanding the implementation context for community sport. British Journal of Sports Medicine, 44(13), 973. https://doi.org/10.1136/bjsm.2008.056069 
Ageberg, E., Bunke, S., Lucander, K., Nilsen, P., \& Donaldson, A. (2019). Facilitators to support the implementation of injury prevention training in youth handball: A concept mapping approach. Scandinavian Journal of Medicine \& Science in Sports, 29(2), 275-285.

https://doi.org/10.1111/sms.13323
Joy, E. A., Taylor, J. R., Novak, M. A., Chen, M., Fink, B. P., \& Porucznik, C. A. (2013). Factors Influencing the Implementation of Anterior Cruciate Ligament Injury Prevention Strategies by Girls Soccer Coaches. The Journal of Strength \& Conditioning Research, 27(8). https://doi.org/10.1519/jsc.0b013e31827ef12e

\title{
ВПРОВАДЖЕННЯ ВПРАВ ОЛТRС 3 ПОПЕРЕДЖЕННЯ ТРАВМ У ПРОФЕСІЙНОМУ ГАНДБОЛІ
}

\author{
Весам Салех А. Аль Аттар ${ }^{1,2,3 \mathrm{ABCDE}}$, Наваф Аль Масуді ${ }^{1 \mathrm{BCDE}}$, \\ Алі Аль Зубеаді ${ }^{1 \mathrm{CDE}}$, Ахмед Касем ${ }^{1 \mathrm{BCDE}}$ \\ ${ }^{1}$ Університет Умм Аль Кура \\ ${ }^{2}$ Університет Сіднея \\ ${ }^{3}$ Базельський університет \\ Авторський вклад: А - дизайн дослідження; В - збір даних; C - статаналіз; D - підготовка рукопису; Е - збір коштів \\ Реферат. Стаття: 6 с., 4 табл., 29 джерел.
}

Мета дослідження. Вправи по запобіганню гандбольних травм - це науково обгрунтовані вправи, запропоновані Центром досліджень спортивного травматизму в Осло (OSTRC). Це дослідження мало на меті оцінити реалізацію вправ OSTRC щодо запобігання травматизму серед професійних гандболістів у країнах Ради співпраці країн Перської затоки (GCC).

Матеріали і методи. Інтернет-опитування 3 метою отримання інформації щодо виконання вправ OSTRC із запобігання травматизму в гандболі було розповсюджено серед 267 професійних гандболістів у шести країнах GCC.
Результати. Загалом в опитуванні взяли участь 250 гандболістів із країн GCC (рівень відповіді 93,6\%). Середнє значення ( \pm SD (стандартне відхилення)) загальної оцінки впровадження становило $13( \pm 2,558)$, без статистично значущої різниці між країнами GCC, значення Р становило 0,123. Найвищий середній бал був показаний в Бахрейну в 13,60 $( \pm 2,614)$, тоді як найнижчий був у Катара в $12,10( \pm 2,427)$.

Висновки. У поточному дослідженні повідомлялося про низький рівень виконання вправ OSTRC з гандболу серед гандболістів у країнах GCC.

Ключові слова: атлетичні травми, опитування та анкетування, вправи, спорт.

\section{Information about the authors:}

Wesam Saleh A. Al Attar, PT, MSc, PhD: wsattar@uqu.edu.sa; https://orcid.org/0000-0003-1907-4539; Department of Physical Therapy, Faculty of Applied Medical Sciences, Umm Al Qura University, PO Box: 715, Makkah, 21955, Saudi Arabia. Discipline of Exercise and Sport Science, Faculty of Medicine and Health Sciences, The University of Sydney, Australia; Department of Sport, Exercise and Health, Faculty of Medicine, University of Basel, Basel, Switzerland.

Nawaf Al Masoudi, PT, MSc: s44180863@st.uqu.edu.sa; https://orcid.org/0000-0003-2601-6548; Department of Physical Therapy, Faculty of Applied Medical Sciences, Umm Al Qura University, PO Box: 715, Makkah, 21955, Saudi Arabia.

Ali Al Zubeadi, PT, MSc: s44180545@st.uqu.edu.sal; https://orcid.org/0000-0001-6520-4862; Department of Physical Therapy, Faculty of Applied Medical Sciences, Umm Al Qura University, PO Box: 715, Makkah, 21955, Saudi Arabia.

Ahmed Qasem, PT, MSc: s44180517@st.uqu.edu.sa; https://orcid.org/0000-0002-9977-9266; Department of Physical Therapy, Faculty of Applied Medical Sciences, Umm Al Qura University, PO Box: 715, Makkah, 21955, Saudi Arabia.

Cite this article as: Wesam Saleh A. Al Attar, Nawaf Al Masoudi, Ali AL Zubeadi, \& Ahmed Qasem, (2021). Implementation of the OSTRC Handball Injury Prevention Exercises in Professional Handball. Teoriâ ta Metodika Fizičnogo Vihovannâ, 21(2), 136-141. https://doi.org/10.17309/tmfv.2021.2.06

Received: 12.03.2021. Accepted: 18.05.2021. Published: 25.06.2021

This work is licensed under a Creative Commons Attribution 4.0 International License (http://creativecommons.org/licenses/by/4.0). 